\title{
Asystasia gangetica var. krishnae (Acanthaceae): A new variety from Kerala, India
}

\author{
Dhruvan Tandyekkal, A.G. Pandurangan \& N. Mohanan \\ Jawaharlal Nehru Tropical Botanic Garden and Research Institute, Palode, \\ Thiruvananthapuram, Kerala - 695 562, India. \\ E-mail: tdhruvan@gmail.com
}

\begin{abstract}
Asystasia gangetica var. krishnae Dhruvan, Pandur. \& Mohanan, is described as a new variety from the southern Western Ghats of Kerala.
\end{abstract}

Keywords: Acanthaceae, Asystasia, Kerala, New variety, Western Ghats.

\section{Introduction}

The genus Asystasia Blume (Acanthaceae) has over 70 species, distributed in the Old World (Mabberley, 2017). In a recent compilation Karthikeyan et al. (2009) included nine species and two varieties in India, of which six are reported from Kerala (Sasidharan, 2013). During a recent field exploration in Western Ghats of Kerala, the first author collected an interesting specimen resembling Asystasia gangetica (L.) T. Anderson, from the forest cuttings near Kulathupuzha Forest Range Office in Kollam district. Later, it was collected from many neighbouring places in the district. Scrutiny of the relevant literature (Anderson, 1867-1869; Karthikeyan et al., 2009; Sasidharan, 2013) and critical examination of the specimens and type of Asystasia gangetica helped the authors to recognize it as a new variety which is described and illustrated here.

Asystasia gangetica (L.) T. Anderson var. krishnae Dhruvan, Pandur. \& Mohanan, var. nov. Figs. 1 \& 2

Differs from the typical variety in having larger (2-9 $\mathrm{cm}$ long), mostly ovate-lanceolate leaves with longattenuate bases, violet-purple bracts and bracteoles, smaller $(1.8-2 \mathrm{~cm})$ simple hairy, corolla limb, and anthers with a vertical violet-black band on the sides.

Received: 28.01.2019; Revised \& Accepted: 03.06.2019 Published Online: 30.06.2019
Type: INDIA, Kerala, Kollam district, near Kulathupuzha Range Office, 100 m, 18.04.2017, Dhruvan T. 85005 (holo TBGT!; iso CALI!, MH!).

Procumbent or subscandent herbs, trailing at the base and rooting at the lower nodes, 30-60 cm long; stem branched, quadrangular, puberulent; internodes 2.5-12 cm long; nodes jointed, swollen, $0.2-0.5 \mathrm{~cm}$ across. Leaves opposite, decussate; petioles $0.2-6.5 \mathrm{~cm}$ long, adpressedpuberulent; lamina mostly ovate-lanceolate, rarely ovate, $2-9 \times 2.3-4.4 \mathrm{~cm}$, long-attenuate or rarely obtuse to sub-cordate at base, acuminate to subacute at apex, margins entire, adpressedpuberulent above, puberulent on veins beneath, green, young leaves sometimes with dark purple tinge; lateral veins (5)-7-(8) pairs. Racemes terminal and axillary, 1-sided, spike-like, 12-25 cm long, 6-12-flowered, lax; bracts lanceolate, $0.2 \mathrm{~cm}$ long, acute to acuminate at apex, violetpurple, ciliate along margins, persistent; bracteoles similar to bracts, $0.15 \mathrm{~cm}$ long. Flowers $1.8-2$ $\mathrm{cm}$ across, white, with a violet-purple blotch in the middle lobe of lower lip; pedicels $0.08-0.1$ $\mathrm{cm}$ long, densely puberulent. Calyx tube $0.1 \mathrm{~cm}$ long, 5-lobed; sepals 5, linear-lanceolate, 0.3-0.35 $\mathrm{cm}$ long, puberulent on the back. Corolla limb sub-orbicular, 1.8-2 cm across; tube funnelshaped, pilose inside below the insertion of the stamens, lower narrow portion $0.5-0.55 \mathrm{~cm}$ long, c. $0.25 \mathrm{~cm}$ wide, glabrous outside, the upper ventricose portion $0.7-0.8 \mathrm{~cm}$ long, $0.7-0.8 \mathrm{~cm}$ broad at the mouth, pubescent outside; lobes 5 , almost rounded, $0.5-0.6 \mathrm{~cm}$ in expanse. Stamens 4 , didynamous, inserted at $0.5 \mathrm{~cm}$ above the base of corolla tube, included; filaments of the shorter stamens $0.4-0.5 \mathrm{~cm}$ long, longer ones $0.7-0.8$ 


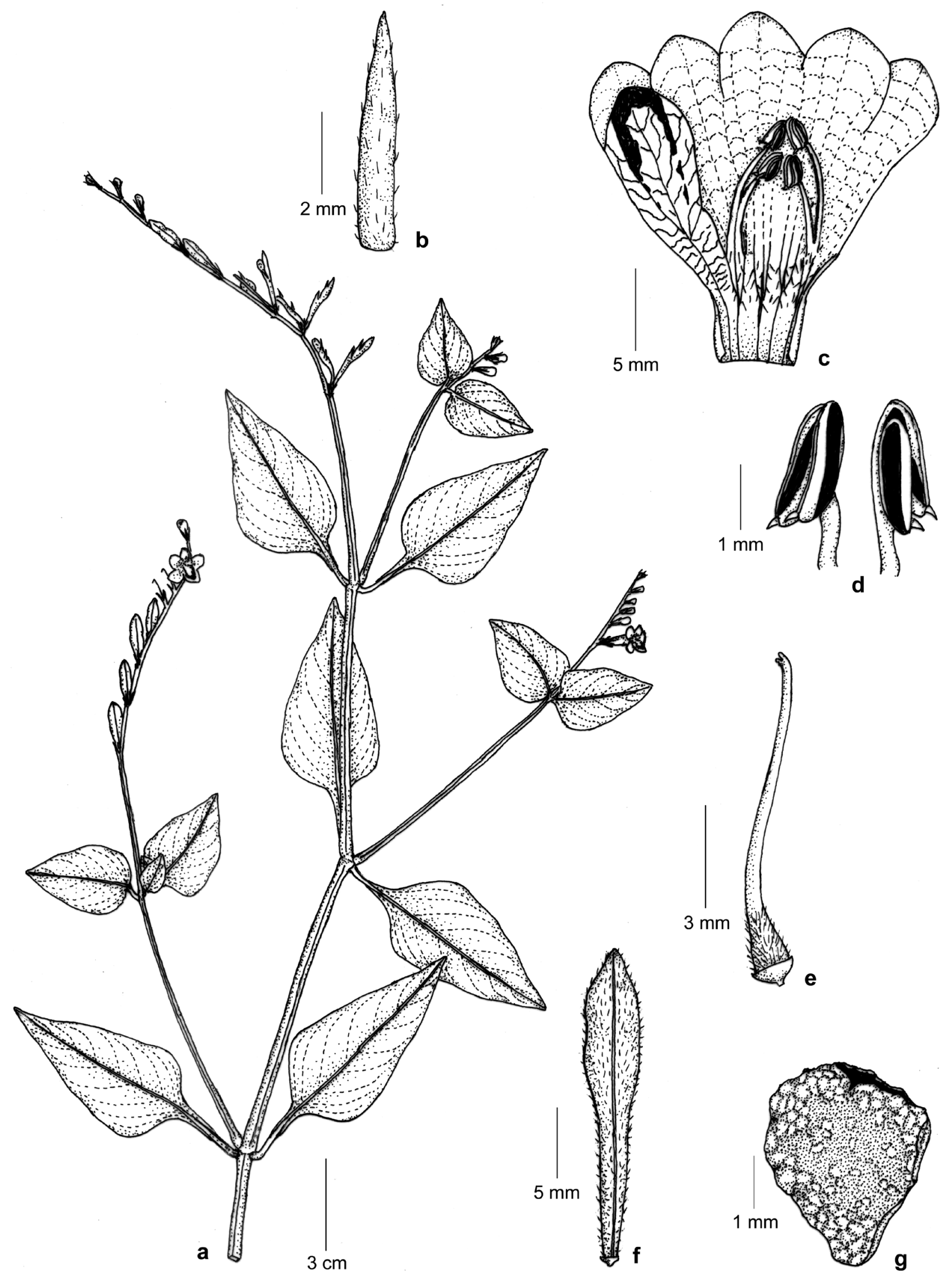

Fig. 1. Asystasia gangetica var. krishnae Dhruvan, Pandur. \& Mohanan var. nov.: a. Flowering-twig; b. Sepal; c. Corolla split-open; d. Anthers; e. Gynoecium; f. Capsule; g. Seed. 
$\mathrm{cm}$ long, connate at the base in pairs, glabrous except for few glandular hairs at the base; anthers oblong, c. $0.16 \mathrm{~cm}$ long, muticous, spurred, white with a vertical violet-black band on the sides. Ovary oblong-lanceolate, $0.16-0.18 \mathrm{~cm}$ long, densely pubescent, basally surrounded by fleshy, dull white, nectariferous disc, 2-celled; ovules 2 in each cell; style linear, $0.8-1 \mathrm{~cm}$ long, white, basally hispid; stigma shortly 2-fid, smooth. Capsules clavate, $2.3-2.5 \times 0.3-0.35 \mathrm{~cm}$, densely puberulent, opening widely in a reflexed curve. Seeds 3 or 4 , suborbicular, compressed, $c$. $0.3 \mathrm{~cm}$ across, subtuberculate, rugose, angular with double dentate margins; margins slightly thickened, lobes slightly defined.
Flowering \& fruiting: Throughout the year.

Habitat: Occasionally found in shady places in moist deciduous forests, in loamy-lateritic soils, at an elevation of about $100 \mathrm{~m}$.

Distribution: Hitherto known only from the type locality.

Specimens examined: INDIA, Kerala, Kollam district, Kalladakarikakam, near Madathra, 100 m, 12.09.2017, Dhruvan T85019 (TBGT!); Attupuram, near Kadakkal, 90 m, 22.10.2018, Dhruvan T85027 (TBGT!).

Etymology: The epithet 'Krishnae' refers to its violet-black coloured band on the sides of anthers.
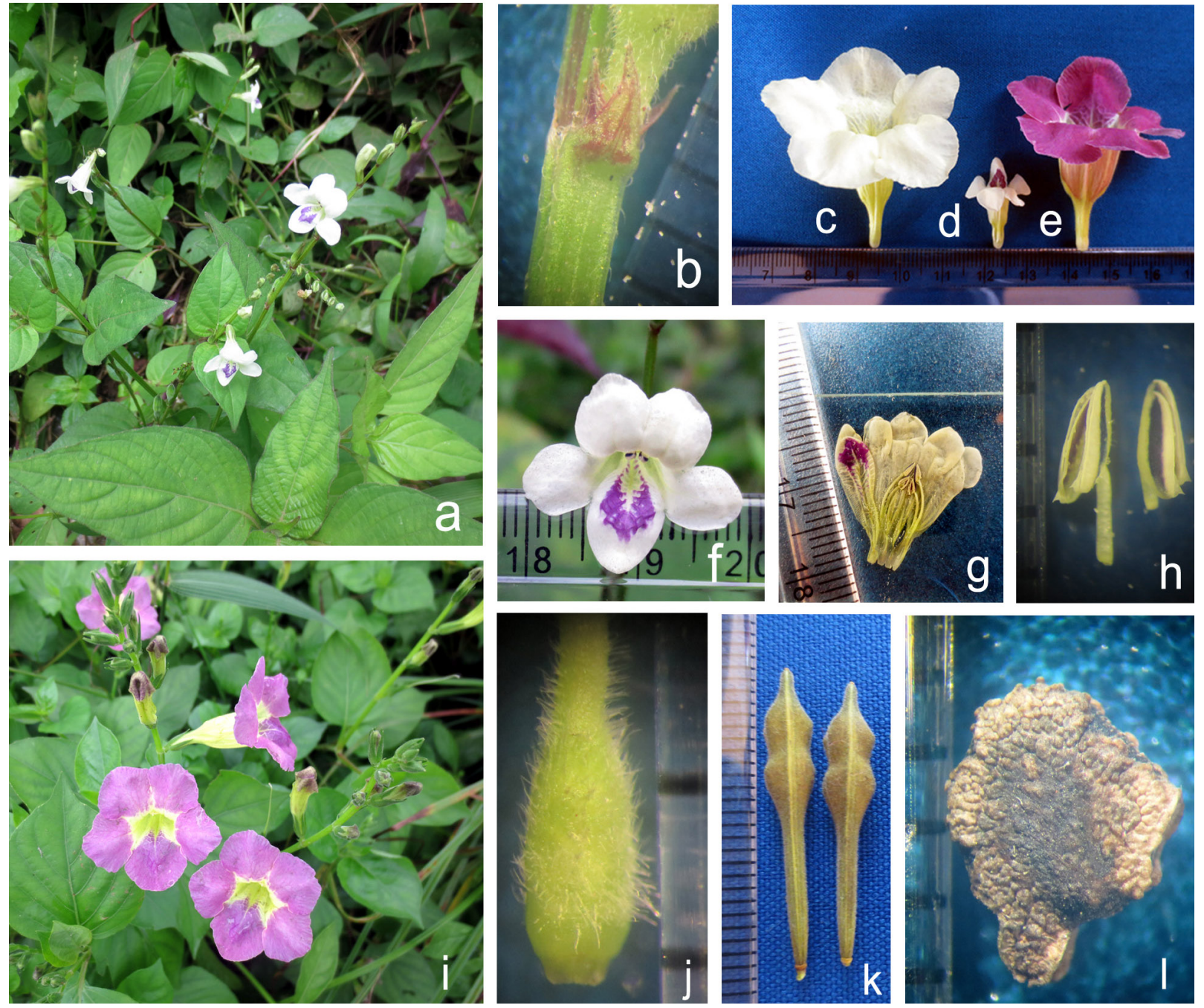

Fig. 2. Asystasia gangetica var. krishnae Dhruvan, Pandur. \& Mohanan var. nov. (a, b, d, f, g, h, j, k, l): a. Habit; b. Internode showing purple bract and bracteoles; d. Corolla side view; f. Corolla front view; g. Corolla split-open; h. Anthers; j. Ovary; k. Capsules; I. Seed. Asystasia gangetica var. gangetica (c, e, i): c, e. Corolla side views; i. Habit. 
Table 1. Diagnostic morphological differences between Asystasia gangetica var. krishnae and A. gangetica var. gangetica

\begin{tabular}{|l|l|l|}
\hline \multicolumn{1}{|c|}{ Characters } & \multicolumn{1}{|c|}{ Asystasia gangetica var. krishnae } & \multicolumn{1}{c|}{ A. gangetica var. gangetica } \\
\hline Lamina & $\begin{array}{l}\text { Mostly ovate-lanceolate, rarely ovate, } \\
\text { base obtuse to truncate, long-attenuate }\end{array}$ & $\begin{array}{l}\text { Ovate, ovate-deltoid to elliptic-ovate, } \\
\text { base obtuse to sub-cordate, rarely } \\
\text { attenuate }\end{array}$ \\
\hline $\begin{array}{l}\text { Colour of bracts \& } \\
\text { bracteoles }\end{array}$ & Violet-purple & Green \\
\hline Corolla-limb & $\begin{array}{l}1.8-2 \mathrm{~cm} \text { across (size consistent both in } \\
\text { the dry and rainy season) }\end{array}$ & $\begin{array}{l}3.5-4.6 \mathrm{~cm} \text { across (size increases to a } \\
\text { maximum of } 4.6 \mathrm{~cm} \text { in the rainy season) }\end{array}$ \\
\hline $\begin{array}{l}\text { Middle lobe of } \\
\text { lower lip }\end{array}$ & $\begin{array}{l}\text { Always with a violet-purple area } \\
\text { With or without a violet-purple area }\end{array}$ \\
\hline Anthers & $\begin{array}{l}\text { Pale yellow with a vertical violet-black } \\
\text { band on either sides }\end{array}$ & Pale yellow throughout \\
\hline
\end{tabular}

\section{Acknowledgements}

The authors are thankful to Dr. R. Prakashkumar, Director, JNTBGRI for facilities and Kerala Forest Department for permission to collect specimens.

\section{Literature Cited}

ANDERSON T. 1867-1869. List of Acanthaceae, cultivated in the Royal Botanical Gardens, Calcutta. Journal of Agricultural and Horticultural Society 3 : 265-289.
KARTHIKEYAN S., SANJAPPA M. \& S. MOORTHY 2009. Flowering Plants of India. Volume 1. Dicotyledons (Acanthaceae-Avicenniaceae). Botanical Survey of India, Kolkata. pp. 4-5.

MABBERLEY D.J. 2017. Mabberley'sPlant-Book: A portable dictionary of plants, their classifications and uses. $\left(4^{\text {th }}\right.$ edition). Cambridge University Press, Cambridge.

SASIDHARAN N. 2013. Flowering plants of Kerala: CD-ROM ver. 2.0. Kerala Forest Research Institute, Peechi, Kerala. 